\title{
Two Stage Efficiency Analysis of Indian Public and Private Sector Banks in the Context of OBS\#
}

\author{
Pushkala Narasimhan' ${ }^{1}$ and K. A. Venkatesh ${ }^{2 *}$ \\ ${ }^{1} A P, P G$ Department of Commerce, \\ ${ }^{2}$ Professor, Department of Math and Computer Science, Myanmar Institute of \\ Information Technology (MIIT), Myanmar, Burma
}

\begin{abstract}
Efficiency is the only criteria to grow and sustain in the competitive markets. Due to technological innovations and emerging global market paradigm, any business organization is compelled to perform better than the yester-years. Banking sectors is one of the major players in the national economy and hence identifying the efficient ones and reducing the inefficient ones is a important task. Profitability is concerned, one look at the balance sheets and decide the rate of growth or decline in growth. In the banking context, one has to look in to the Off-Balance Sheet (OBS) items to study the growth pattern, rather than just depending on the balance Sheets alone. In general the OBS items appear as foot notes. Generally the efficiencies of financial institutions are decided based the standard approaches such as Ratio Analysis, a certain extend Regression Analysis.

A large number of studies based on OBS in the context of US banking sector and European Banking sectors have been done. A few research articles only available in Indian banking scenario in the context of OBS. This paper aims to bridge this gap. Last ten years good number of articles appeared based on Data Envelopment Analysis to study the efficiencies of various industrial sectors. In this paper, we have deployed the two-stage DEA to study the efficiencies of the public and private sector banks in the context of OBS.
\end{abstract}

Keywords: Data Envelopment Analysis (DEA), Frontier, Effectiveness, Off-Balance Sheet (OBS)

\section{Introduction}

The growth of banking sector in any geographical region is an indication of the regional growth. In a nutshell, banks are the backbone of any nation's economy. Till two decades ago, only the government was a major player and enjoying the monopoly in this segment. Due to liberalization and a change in the policy paradigm, many players entered into this sector slowly. The advancement of technology and the implementation of technology, the private players are forerunners who made a lead role and started ripping the benefits much before its counterparts, public sector banks. Hence a volume of articles appeared in studying the performance and effectiveness of banking. Most articles appeared in this arena based on CAMEL model and based on ratio analysis. The articles in this direction have used one or two parameters (or both) to measure the performance: Return On Assets (ROA) and Return On Equity (ROE). A very few articles only appeared using OBS items as one of the parameters. In this article, we used a non-parametric model, Data Envelopment Analysis (DEA) to study the performance with OBS as a parameter. Interestingly, Non-closed two-stage DEA was applied to study the efficiency of Public and Private Sector Banks in India, in the context 
of OBS. In this article, the study focused on 26 Public sector banks and 19 private sector banks for the period of 3 years starting from 2015 to 2017 and hence 135 bank-years.

The remaining part of this article is presented as, section 2 on review of literature, section 3 deals with brief introduction on DEA, section 4 presents the results and discussions and section 5 is on conclusions and future directions.

\section{Review of Literature}

Data Envelopment Analysis is deployed to study the performance of almost in every industrial sector. In this section, reviews were on the deployment of DEA in banking sector. However, there will be reviews of papers from DEA literature too. To start with, DEA was introduced by Charnes, Cooper and Rhodes (CCR) in 1978 and later Banker, Cooper and Charnes modified the first model and it is called as BCC model. 1997 Berger and Humphrey did a review article which consists of efficiency studies of 130 financial institutions, including commercial banks (Berger, 1997).

Bhide, et al., did study on weakness of banks in the context of critical reforms and analyzed the issues and challenges (Bhide, 2002).

De studied the relationship between the ownership and efficiency and the impact of reforms on efficiency of Indian banks (De, 2004).

Another study utilized the DEA to determine the efficiency of performance of Indian Banking sector during Post-Reform and Global Financial Crisis (Kumar, 2012).

In another article, it was discussed that size of the bank and its impact on efficiency (Ray, 2004) The same authors discussed on the cost and profit efficiency of Indian banking (Ray, 2010).

Pushkala et al. did a comparative study on the impact of OBS and Liquidity (Pushkala, 2017) of both public and private sector banks in India.
Venkatesh et al., studied the profit efficiency of Foreign Banks in India in the context of OBS using DEA approach for 5 years (Venkatesh, 2016).

Other Review on efficiency analysis of Banks using DEA (Singh, 2004).

Gulati and Sunil Kumar applied two-stage NDEA to identify the intermediation and operational efficiencies in the Indian Banking scenario and observed that public sector banks are efficient than their counterparts in the intermediation efficiency whereas the private sector banks are efficient in the operational efficiency in the production process and applied the bootstrapped truncated regression to identify the influential factors towards the operational and intermediation efficiencies (Gulati, 2017).

Venkatesh et al., (2017) found that the role of OBS is the most influential factor on the performance of Public sector Banks (Venkatesh, Off-Balance Sheet items and Performance Evaluation of Prublic and Private Sector Banks in India: A DEA apporach).

\section{Data Envelopment Analysis}

Data Envelopment Analysis (DEA) is one of the nonparametric methods which is deployed in most of the efficiency studies. This method was developed by Charnes, Cooper \& Rhodes in 1978, and popularly known as CCR model. At a later stage BCC model was introduced. In the last decade, about 7000 articles appeared on studying efficiencies of various sectors such as Finance, Banking, Healthcare and Agriculture. DEA is one of the predominant models in studying efficiencies.

The basic CCR model is given by

$$
\operatorname{Max}_{\mathrm{u}, \mathrm{v}} \mathrm{z}=\frac{\mathrm{u}_{1} \mathrm{y}_{1,0}+\mathrm{u}_{2} \mathrm{y}_{2,0}+\ldots .+\mathrm{u}_{\mathrm{n}} \mathrm{y}_{\mathrm{n}, 0}}{\mathrm{v}_{1} \mathrm{x}_{1,0}+\mathrm{v}_{2} \mathrm{x}_{2,0}+\ldots+\mathrm{v}_{\mathrm{m}} \mathrm{x}_{\mathrm{m}, 0}}
$$

Subject to the constraints

$$
\begin{gathered}
\frac{\mathrm{u}_{1} \mathrm{y}_{1, \mathrm{j}}+\mathrm{u}_{2} \mathrm{y}_{2, \mathrm{j}}+\ldots .+\mathrm{u}_{\mathrm{n}} \mathrm{y}_{\mathrm{n}, \mathrm{j}}}{\mathrm{v}_{1} \mathrm{x}_{1, \mathrm{j}}+\mathrm{v}_{2} \mathrm{x}_{2, \mathrm{j}}+\ldots+\mathrm{v}_{\mathrm{m}} \mathrm{x}_{\mathrm{m}, \mathrm{j}}} \\
\mathrm{u}_{\mathrm{i}} \geq 0(1 \leq \mathrm{i} \leq \mathrm{n}) \& \mathrm{v}_{\mathrm{j}} \geq 0,(1 \leq \mathrm{j} \leq \mathrm{m})
\end{gathered}
$$


The equivalent linear programing problem as follows:

$$
\operatorname{Max}_{u, v} z=u_{1} y_{1, j}+u_{2} y_{2, j}+\ldots .+u_{n} y_{n, j}
$$

Subject to the constraints:

$$
\begin{gathered}
\mathrm{v}_{1} \mathrm{x}_{1, \mathrm{j}}+\mathrm{v}_{2} \mathrm{x}_{2, \mathrm{j}}+\ldots+\mathrm{v}_{\mathrm{m}} \mathrm{x}_{\mathrm{m}, \mathrm{j}}=1 \\
\mathrm{u}_{1} \mathrm{y}_{1, \mathrm{j}}+\mathrm{u}_{2} \mathrm{y}_{2, \mathrm{j}}+\ldots+\mathrm{u}_{\mathrm{n}} \mathrm{y}_{\mathrm{n}, \mathrm{j}} \leq \mathrm{v}_{1} \mathrm{x}_{1, \mathrm{j}}+\mathrm{v}_{2} \mathrm{x}_{2, \mathrm{j}}+\ldots+\mathrm{v}_{\mathrm{m}} \mathrm{x}_{\mathrm{m}, \mathrm{j}} \\
\mathrm{u}_{\mathrm{i}} \geq 0(1 \leq \mathrm{i} \leq \mathrm{n}) \& \mathrm{v}_{\mathrm{j}}(1 \leq \mathrm{j} \leq \mathrm{m})
\end{gathered}
$$

The efficiency can be obtained using various returns to scale such as Constant Return Scale (CRS), Variable Returns to Scale (VRS), Decreasing Returns to the Scale (DRS), Increasing Returns to the Scale (IRS), Free Disposal Hull (FDH) and so on. These are measures which are based on the distance between the efficiency of the firm to the frontier. Another important aspect of DEA is that the orientation of either input or output: How to maximize the outputs for the predefined inputs is input orientation whereas the output orientation is the method to minimize the inputs for the predefined outputs. The combination of orientation and returns to scale lead to various efficiencies. The firms or individuals, whose efficiency will be studied is called as Decision Making Units (DMU), in DEA literature.

In this article, a two-stage network DEA was deployed to study the efficiencies of Indian Public and Private sector Banks in the context of OBS. Many researchers utilized two-stage network DEA model in their studies. Originally the two-stage network DEA was presented in Naval Research Logistics (Liang, 2008). The twostage network DEA model is given as:

$$
\operatorname{Max} \sum_{k=1}^{m} u_{k} y_{k 0}
$$

Subject to the constraints

$$
\sum_{k=1}^{m} u_{k} y_{k 0}-\sum_{l=1}^{L} u_{l} z_{l j} \leq 0
$$

$$
\begin{gathered}
\sum_{l=1}^{L} u_{l} z_{l j}-\sum_{i=1}^{n} v_{i} x_{i j} \leq 0 \\
\sum_{i=1}^{n} v_{i} x_{i j}=1 \\
w_{l} \geq 0 \& v_{i} \geq 0,0 \leq l \leq L \& 0 \leq i \leq n \\
u_{k} \geq 0,0 \leq k \leq m
\end{gathered}
$$

\subsection{Data and Methodology}

The inputs for the first stage are Deposits, Borrowings and Share Capital and the outputs are Advances, Money at Call and Short notices, Fixed Assets and Other Assets. In the second stage, the inputs are the scale-efficiency scores of the banks and OBS and the outputs are Interest Income and Other Income (which includes the non-interest Income). In the first stage CRS and VRS input orientation were applied and the scale efficiency is computed as

$$
\text { Scale Efficiency }=\frac{\text { efficiency scores }(C R S-I n)}{\text { efficiency scores }(V R S-i n)}
$$

and the final efficiency is obtained from the second stage is used to compute the ranks of the Private and Public sector Banks. This study is based on the secondary data available on RBI website and the period covered for the study is three years starting from 2015 to 2017 (RBI, 2017). The statistics of the input and output variables of public and private sector banks are given in the Table 1 and 2 respectively.

Table 1. Variables of the study

\begin{tabular}{|l|l|l|l|l|l|}
\hline SCAP & Share Capital & MCAL & Money at Call \& Short Notice & DEPO & Deposits \\
\hline INVEST & Investment & ADV & Advances & BORR & Borrowings \\
\hline FA & Fixed Assets & OA & Other Assets & OBS & Off-Balance Sheet Items \\
\hline OINC & Other Income & INTINC & Interest Income & - & - \\
\hline
\end{tabular}


Table 2. Summary Statistics of input-output variables public sector banks

\begin{tabular}{|l|c|c|c|c|c|}
\hline Variables & Mean & Std. Dev. & Median & Skewness & Kurtosis \\
\hline SCAP & 7384.881 & 5950.109 & 6486.547 & 1.345215 & 1.977322 \\
\hline MCAL & 55121.91 & 92510.25 & 9748.254 & 2.380088 & 5.892791 \\
\hline INVEST & 879231 & 1137258 & 594633.8 & 4.232754 & 19.41983 \\
\hline ADV & 2131476 & 2706034 & 1398605 & 3.695754 & 14.37053 \\
\hline FA & 33586.01 & 51273.45 & 16783.74 & 5.956308 & 42.57485 \\
\hline OA & 163766.1 & 249904.5 & 90116.45 & 4.208249 & 18.39139 \\
\hline DEPO & 2917563 & 3379830 & 2009645 & 3.483452 & 13.26491 \\
\hline BORR & 276548.4 & 547412.1 & 106059.6 & 4.345614 & 19.45894 \\
\hline INTINC & 262394.1 & 301510.5 & 184916.5 & 3.685598 & 14.27296 \\
\hline OINC & 34768.45 & 54575.91 & 19248.54 & 4.258837 & 19.18064 \\
\hline OBS & 1459655 & 2065491 & 655614.2 & 2.848167 & 8.879379 \\
\hline
\end{tabular}

Table 3. Summary Statistics of input-output variables private sector banks

\begin{tabular}{|l|c|c|c|c|c|}
\hline Variables & Mean & Std. Dev. & Median & Skewness & Kurtosis \\
\hline SCAP & 4311.431 & 6300.027 & 2459.295 & 3.516616 & 13.50887 \\
\hline MCAL & 24907.52 & 55805.84 & 2499.733 & 3.499694 & 14.43576 \\
\hline INVEST & 385382 & 534471 & 155570.7 & 1.881199 & 2.306513 \\
\hline ADV & 953776.3 & 1389304 & 397408 & 1.914966 & 2.339954 \\
\hline FA & 10846.82 & 16340.41 & 4686.746 & 2.587297 & 6.784174 \\
\hline OA & 93304.5 & 154520.2 & 31043.01 & 2.116006 & 3.337 \\
\hline DEPO & 1086664 & 1516332 & 502835.6 & 1.971565 & 2.790359 \\
\hline BORR & 233419.9 & 422448.3 & 23239.54 & 2.228791 & 4.314399 \\
\hline INTINC & 123063.4 & 171181.3 & 54196.54 & 1.896604 & 2.329493 \\
\hline OINC & 25755.96 & 43295.92 & 5618.499 & 2.133809 & 3.794034 \\
\hline OBS & 1762304 & 2940973 & 158069.3 & 1.651865 & 1.386165 \\
\hline
\end{tabular}

The correlation among the input and output variables of public and private sector banks are presented in Figure 1 and 2 respectively. From the correlation analysis on public sector banks, OBS is highly interacting in the positive direction with Interest Income, Other Income, Deposits, Borrowings, Other Assets, Advances, Fixed Assets and Money at Call and Share Capital are in the decreasing order of correlation coefficients. Also, it is observed that Share Capital and Money at Call \& Short notice plays a minimal role in determining the efficiencies of DMUs. Moreover, Interest Income and Deposits have attained the perfect correlation of 1 and Advances and deposits are also perfectly correlated with each other in both the DMUs. In case of private sector banks,
OBS is highly interacting with Advances, Interest Income, Other Income, Other Assets, Borrowings, Fixed Assets, and Money at Call \& Short notice and Share Capital. Among the input and output variables, Share Capital has very minimal interaction in both cases.

\subsection{The Two-Stage DEA}

In the first stage DEA, the inputs are Deposits, Borrowings and Share Capital and the outputs are Money at Call \& Short notice, Fixed Assets, Other Assets. We deployed CRS input and VRS input oriented approach to obtain the scale efficiencies of DMUs. In the second stage, the efficiency scores of DMUs obtained in the first stage and OBS are the inputs and the outputs are Interest Income and Other Interest Income to obtain 


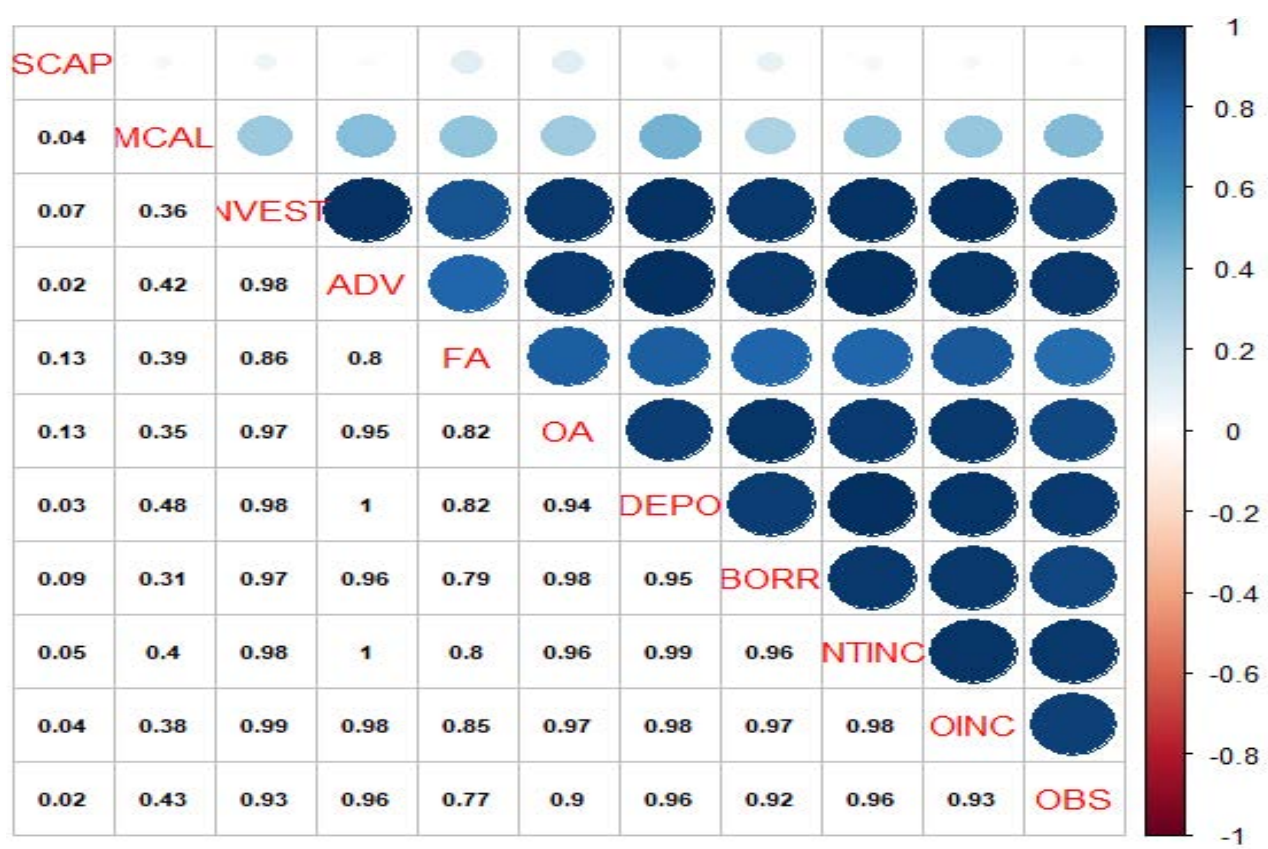

Figure 1. Correlation among the variables public sector banks

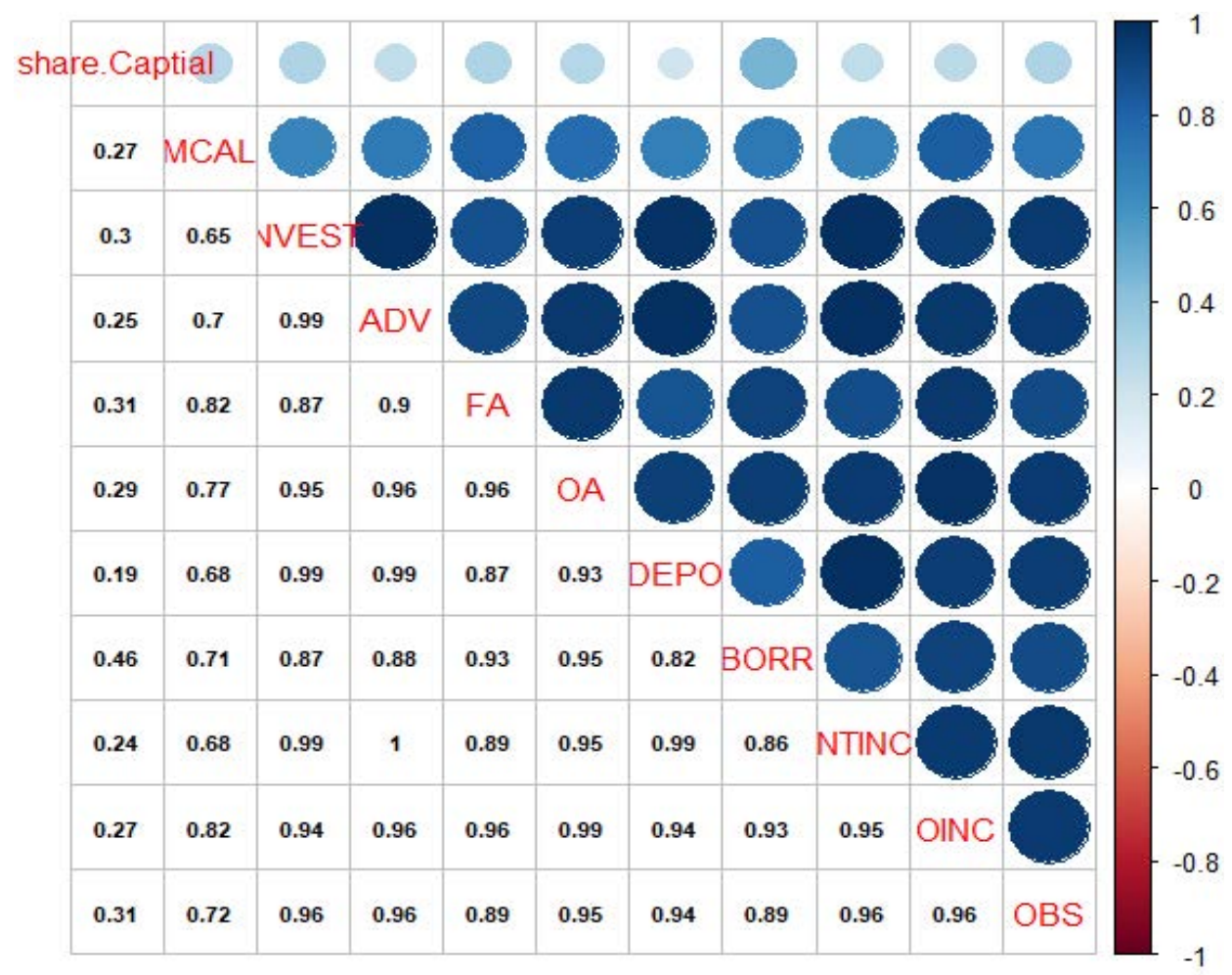

Figure 2. Correlation among the variables - private sector banks.

the scale efficiencies of the DMUs. These inputs and outputs are chosen based on the correlation analysis, even though there is no consistency of choosing the inputs and outputs for any study. There are very few articles appeared for the selection of input and output variables, but there is contradiction among the proven 
results (Farzipoor Saen, 2005). Another article states that in order to identify the inputs and outputs, start with one input and one output, obtain the efficiency scores and subsequently consider second input/output, find the correlation coefficient. Based on this result, add one by one (Luis Daniel Otero, 2012). Share Capital is the only variable not considered in all the above studies, but it is reasonable to consider Share Capital as vital variable in this study because it is the primary most sources of funds to do banking business.

\section{Results and Discussions}

The first stage CRIO, VRIO and Scale efficiencies of private and Public sector banks are presented in Table 3 and 4 respectively. Frontiers are depicted in Figure 3 and 4 (one input variable and the corresponding scale efficiency). In the first stage, it is found that Jammu \& Kashmir Bank is the most inefficient in the year 2015 and the remaining two years it has become efficient one. It is evident that only 6 banks among the considered 19 private banks are fully efficient during the study period.
The efficient private Banks are HDFC, ICICI, Kotak Mahindra Bank, Dhanalakshmi Bank, Tamil Nadu Mercantile Bank and Yes Bank. In case of public sector banks, only five banks are found fully efficient and they are State Bank of Travancore, State Bank of Patiala, State Bank of Mysore, Indian Bank and IDBI.

Like the scale efficiency computed in the first stage, the scale efficiency along with the ranks of public and private sector banks are computed under the second stage too. It is revealed that, no bank is fully efficient but most of the banks are efficient with respect to Variable Returns to Scale and input oriented approach. Three categories of efficiencies of private and public sector banks are given in Table 5 and 6 respectively.

It is learnt from the Table 4 that, Lakshmi Vilas Bank has been continuously attained the perfect efficiency of 1 in 2016 and 2017. Seven private sector banks attained efficiency score of 1 in 2017 which indicates that the private sector banks are trying hard to attain the utmost efficiency.

Table 3. Three efficiency scores 3 years - private sector banks

\begin{tabular}{|c|c|c|c|c|c|c|c|c|c|}
\hline Year & \multicolumn{3}{|c|}{2015} & \multicolumn{3}{|c|}{2016} & \multicolumn{3}{|c|}{2017} \\
\hline Bank & CRIO EFF & VRIO EFF & Scale EFF & CRIO EFF & VRIO EFF & Scale EFF & CRIO EFF & VRIO EFF & Scale EFF \\
\hline Axis Bank Ltd. & 1.000 & 1.000 & 1.000 & 0.960 & 0.970 & 0.990 & 0.976 & 0.978 & 0.998 \\
\hline Catholic Syrian Bank Ltd. & 1.000 & 1.000 & 1.000 & 1.000 & 1.000 & 1.000 & 1.000 & 1.000 & 1.000 \\
\hline City Union Bank Ltd. & 1.000 & 1.000 & 1.000 & 0.974 & 0.976 & 0.998 & 1.000 & 1.000 & 1.000 \\
\hline DCB Bank Ltd. & 1.000 & 1.000 & 1.000 & 1.000 & 1.000 & 1.000 & 1.000 & 1.000 & 1.000 \\
\hline Federal Bank Ltd & 1.000 & 1.000 & 1.000 & 0.957 & 0.960 & 0.997 & 0.966 & 0.969 & 0.997 \\
\hline HDFC Bank Ltd. & 1.000 & 1.000 & 1.000 & 0.979 & 1.000 & 0.979 & 1.000 & 1.000 & 1.000 \\
\hline ICICI Bank Ltd. & 1.000 & 1.000 & 1.000 & 1.000 & 1.000 & 1.000 & 1.000 & 1.000 & 1.000 \\
\hline IDFC Bank Ltd. & 1.000 & 1.000 & 1.000 & 1.000 & 1.000 & 1.000 & 1.000 & 1.000 & 1.000 \\
\hline Jammu \& Kashmir Bank Ltd. & 0.979 & 0.981 & 0.997 & 1.000 & 1.000 & 1.000 & 1.000 & 1.000 & 1.000 \\
\hline Karnataka Bank Ltd. & 1.000 & 1.000 & 1.000 & 0.955 & 0.965 & 0.990 & 1.000 & 1.000 & 1.000 \\
\hline Karur Vysya Bank Ltd. & 0.995 & 1.000 & 0.995 & 0.947 & 0.970 & 0.976 & 0.979 & 1.000 & 0.979 \\
\hline Kotak Mahindra Bank Ltd. & 1.000 & 1.000 & 1.000 & 1.000 & 1.000 & 1.000 & 1.000 & 1.000 & 1.000 \\
\hline Lakshmi Vilas Bank Ltd. & 1.000 & 1.000 & 1.000 & 0.997 & 0.997 & 0.999 & 0.957 & 0.959 & 0.997 \\
\hline Nainital Bank Ltd. & 1.000 & 1.000 & 1.000 & 0.852 & 1.000 & 0.852 & 1.000 & 1.000 & 1.000 \\
\hline RBL Bank Ltd. & 1.000 & 1.000 & 1.000 & 0.941 & 0.947 & 0.994 & 0.945 & 0.957 & 0.987 \\
\hline South Indian Bank Ltd. & 1.000 & 1.000 & 1.000 & 0.960 & 0.965 & 0.994 & 1.000 & 1.000 & 1.000 \\
\hline Tamil Nadu Mercantile Bank Ltd. & 1.000 & 1.000 & 1.000 & 1.000 & 1.000 & 1.000 & 1.000 & 1.000 & 1.000 \\
\hline The Dhanalakshmi Bank Ltd. & 1.000 & 1.000 & 1.000 & 0.960 & 1.000 & 0.960 & 1.000 & 1.000 & 1.000 \\
\hline Yes Bank Ltd. & 1.000 & 1.000 & 1.000 & 0.963 & 0.964 & 1.000 & 1.000 & 1.000 & 1.000 \\
\hline
\end{tabular}


Table 4. Three efficiency scores for 3 years - public sector banks

\begin{tabular}{|c|c|c|c|c|c|c|c|c|c|}
\hline \multirow{2}{*}{$\begin{array}{l}\text { YEAR } \\
\text { Banks }\end{array}$} & \multicolumn{3}{|c|}{2015} & \multicolumn{3}{|c|}{2016} & \multicolumn{3}{|c|}{2017} \\
\hline & CRIO EFF & VRIO EFF & Scale EFF & CRIO EFF & VRIO EFF & Scale EFF & CRIO EFF & VRIO EFF & Scale EFF \\
\hline Allahabad Bank & 0.971 & 0.975 & 1 & 0.971 & 0.97 & 0.997 & 0.96 & 0.97 & 0.995 \\
\hline Andhra Bank & 0.998 & 0.998 & 1 & 0.993 & 1 & 0.997 & 0.96 & 0.96 & 0.998 \\
\hline Bank of Baroda & 0.867 & 1 & 0.87 & 0.866 & 1 & 0.866 & 0.84 & 1 & 0.840 \\
\hline Bank of India & 0.952 & 1 & 0.95 & 0.909 & 0.93 & 0.978 & 0.89 & 0.98 & 0.914 \\
\hline Bank of Maharashtra & 0.994 & 0.995 & 1 & 0.972 & 0.97 & 0.997 & 0.9 & 0.91 & 0.998 \\
\hline Canara Bank & 0.962 & 1 & 0.96 & 0.937 & 1 & 0.937 & 0.92 & 0.95 & 0.970 \\
\hline Central Bank of India & 0.99 & 0.99 & 1 & 1 & 1 & 1 & 0.91 & 1 & 0.909 \\
\hline Corporation Bank & 1 & 1 & 1 & 0.985 & 0.99 & 0.999 & 1 & 1 & 1.000 \\
\hline Dena Bank & 0.972 & 0.98 & 0.99 & 0.96 & 0.96 & 1 & 1 & 1 & 1.000 \\
\hline IDBI Bank Limited & 1 & 1 & 1 & 1 & 1 & 1 & 1 & 1 & 1.000 \\
\hline Indian Bank & 1 & 1 & 1 & 1 & 1 & 1 & 1 & 1 & 1.000 \\
\hline Indian Overseas Bank & 0.944 & 0.95 & 0.99 & 0.959 & 0.97 & 0.994 & 0.93 & 0.93 & 1.000 \\
\hline Oriental Bank of Commerce & 1 & 1 & 1 & 0.987 & 0.99 & 0.994 & 0.99 & 1 & 0.988 \\
\hline Punjab And Sind Bank & 0.98 & 1 & 0.98 & 0.982 & 1 & 0.982 & 0.99 & 1 & 0.986 \\
\hline Punjab National Bank & 0.96 & 0.986 & 0.97 & 0.927 & 0.94 & 0.986 & 0.92 & 1 & 0.921 \\
\hline Syndicate Bank & 0.955 & 0.969 & 0.99 & 0.941 & 0.95 & 0.987 & 0.95 & 0.98 & 0.974 \\
\hline UCO Bank & 0.939 & 0.946 & 0.99 & 1 & 1 & 1 & 1 & 1 & 1.000 \\
\hline Union Bank of India & 0.979 & 0.99 & 0.99 & 0.969 & 0.99 & 0.983 & 0.94 & 0.95 & 0.995 \\
\hline United Bank of India & 1 & 1 & 1 & 1 & 1 & 1 & 1 & 1 & 1.000 \\
\hline Vijaya Bank & 0.953 & 0.956 & 1 & 0.96 & 0.97 & 0.991 & 0.97 & 0.97 & 0.996 \\
\hline State Bank of Bikaner \& Jaipur & 1 & 1 & 1 & 0.983 & 1 & 0.983 & 1 & 1 & 1.000 \\
\hline State Bank of Hyderabad & 1 & 1 & 1 & 1 & 1 & 1 & 1 & 1 & 1.000 \\
\hline State Bank of India & 0.995 & 1 & 1 & 1 & 1 & 1 & 1 & 1 & 1.000 \\
\hline State Bank of Mysore & 1 & 1 & 1 & 1 & 1 & 1 & 1 & 1 & 1.000 \\
\hline State Bank of Patiala & 1 & 1 & 1 & 1 & 1 & 1 & 1 & 1 & 1.000 \\
\hline State Bank of Travancore & 1 & 1 & 1 & 1 & 1 & 1 & 1 & 1 & 1.000 \\
\hline
\end{tabular}

Frontier

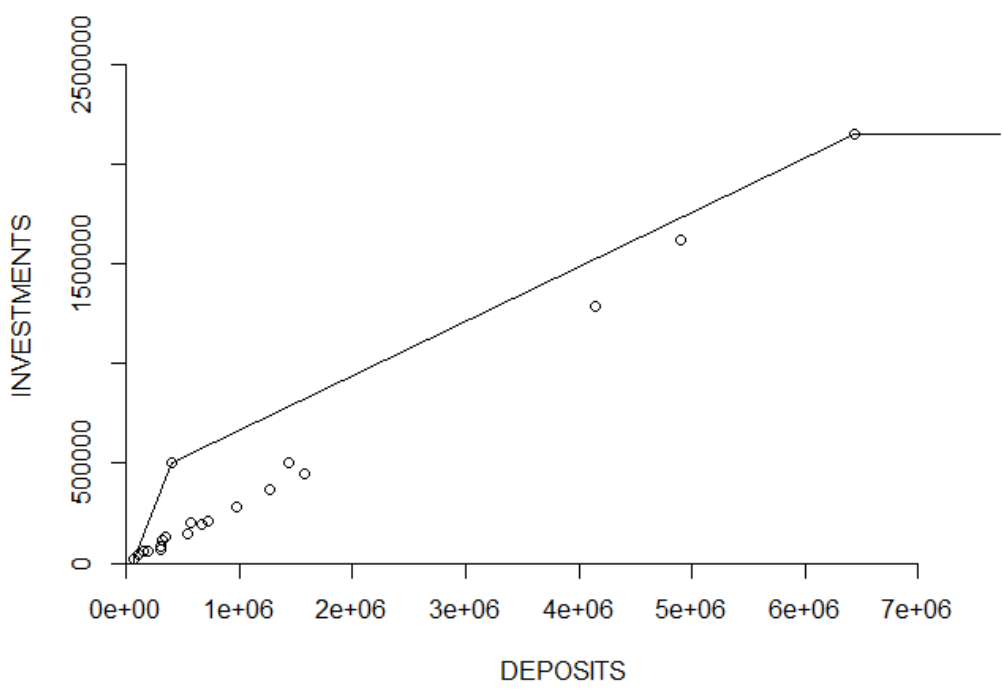

Figure 3. First Stage Frontier. 


\section{Second_Stage_Frontier}

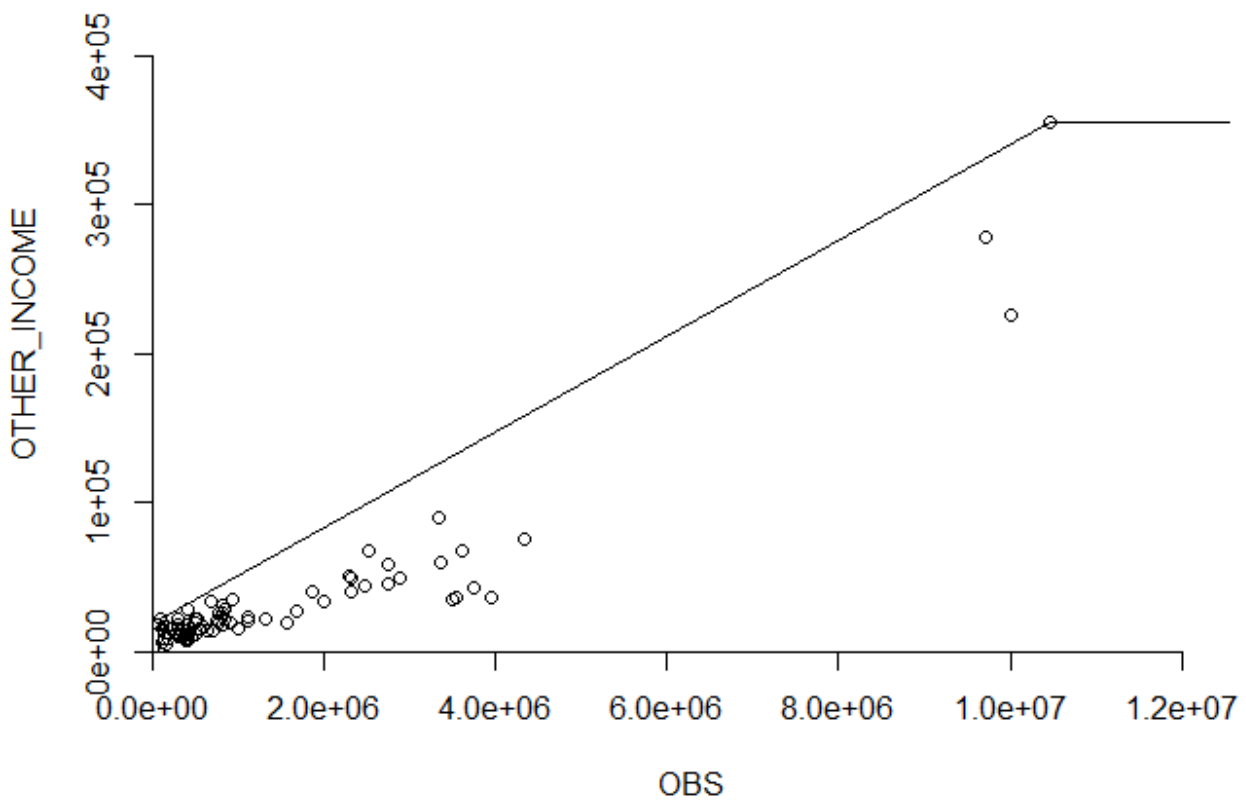

Figure 4. Second Stage Frontier

Table 5. Efficiency scores $2^{\text {nd }}$ stage - private banks

\begin{tabular}{|c|c|c|c|c|c|c|c|c|c|}
\hline \multirow{2}{*}{$\begin{array}{l}\text { Year } \\
\text { Bank }\end{array}$} & \multicolumn{3}{|l|}{2015} & \multicolumn{3}{|l|}{2016} & \multicolumn{3}{|l|}{2017} \\
\hline & CRIO EFF & VRIO EFF & Scale EFF & CRIO EFF & VRIO EFF & Scale EFF & CRIO EFF & VRIO EFF & Scale EFF \\
\hline Axis Bank & 0.815 & 0.877 & 0.930 & 0.888 & 0.910 & 0.976 & 0.981 & 0.983 & 0.998 \\
\hline Catholic Syrian Bank & 1.000 & 1.000 & 1.000 & 0.965 & 0.971 & 0.994 & 1.000 & 1.000 & 1.000 \\
\hline City Union Bank & 0.475 & 0.816 & 0.582 & 0.525 & 0.834 & 0.629 & 0.570 & 0.849 & 0.671 \\
\hline Dcb Bank Ltd. & 0.472 & 0.757 & 0.623 & 0.662 & 0.782 & 0.846 & 0.660 & 0.797 & 0.828 \\
\hline Dhanlaxmi Bank & 0.889 & 0.915 & 0.971 & 0.912 & 0.950 & 0.961 & 1.000 & 1.000 & 1.000 \\
\hline Federal Bank & 0.941 & 0.962 & 0.978 & 0.870 & 0.964 & 0.903 & 1.000 & 1.000 & 1.000 \\
\hline HDFC Bank & 0.708 & 0.918 & 0.771 & 0.949 & 0.970 & 0.978 & 1.000 & 1.000 & 1.000 \\
\hline ICICI Bank & 0.837 & 0.939 & 0.891 & 0.287 & 0.733 & 0.391 & 0.377 & 0.753 & 0.500 \\
\hline Indusind Bank & 0.562 & 0.764 & 0.736 & 0.563 & 0.776 & 0.725 & 0.525 & 0.790 & 0.664 \\
\hline Ing Vysya Bank & 0.295 & 0.746 & 0.396 & 0.848 & 0.928 & 0.913 & 1.000 & 1.000 & 1.000 \\
\hline Jammu \& Kashmir Bank Ltd. & 0.812 & 0.912 & 0.890 & 0.838 & 0.941 & 0.890 & 1.000 & 1.000 & 1.000 \\
\hline Karnataka Bank Ltd. & 0.727 & 0.893 & 0.814 & 0.845 & 0.933 & 0.906 & 0.873 & 0.963 & 0.907 \\
\hline Karur Vysya Bank & 0.743 & 0.891 & 0.834 & 0.640 & 0.785 & 0.815 & 0.907 & 0.940 & 0.965 \\
\hline Kotak Mahindra Bank Ltd. & 1.000 & 1.000 & 1.000 & 0.630 & 0.816 & 0.772 & 0.893 & 0.932 & 0.959 \\
\hline Lakshmi Vilas Bank & 0.664 & 0.811 & 0.819 & 1.000 & 1.000 & 1.000 & 1.000 & 1.000 & 1.000 \\
\hline Nainital Bank & 1.000 & 1.000 & 1.000 & 0.373 & 0.752 & 0.496 & 0.483 & 0.787 & 0.614 \\
\hline RBL & 0.353 & 0.766 & 0.461 & 0.715 & 0.885 & 0.807 & 0.990 & 1.000 & 0.990 \\
\hline South Indian Bank & 0.573 & 0.838 & 0.683 & 0.446 & 0.798 & 0.559 & 0.500 & 0.804 & 0.622 \\
\hline Tamil Nadu Mercantile Bank Ltd. & 0.436 & 0.793 & 0.550 & 0.886 & 0.907 & 0.978 & 0.742 & 0.788 & 0.943 \\
\hline Yes Bank Ltd. & 0.362 & 0.766 & 0.473 & 0.461 & 0.776 & 0.595 & 0.579 & 0.794 & 0.730 \\
\hline
\end{tabular}


Table 6. Efficiency scores $2^{\text {nd }}$ stage - public sector banks

\begin{tabular}{|c|c|c|c|c|c|c|c|c|c|}
\hline Year & \multicolumn{3}{|c|}{2015} & \multicolumn{3}{|c|}{2016} & \multicolumn{3}{|c|}{2017} \\
\hline Bank & $\begin{array}{c}\text { CRIO } \\
\text { EFF }\end{array}$ & $\begin{array}{c}\text { VRIO } \\
\text { EFF } \\
\end{array}$ & $\begin{array}{c}\text { Scale } \\
\text { EFF }\end{array}$ & $\begin{array}{c}\text { CRIO } \\
\text { EFF }\end{array}$ & $\begin{array}{c}\text { VRIO } \\
\text { EFF } \\
\end{array}$ & $\begin{array}{c}\text { Scale } \\
\text { EFF }\end{array}$ & $\begin{array}{c}\text { CRIO } \\
\text { EFF }\end{array}$ & $\begin{array}{c}\text { VRIO } \\
\text { EFF }\end{array}$ & $\begin{array}{c}\text { Scale } \\
\text { EFF }\end{array}$ \\
\hline Allahabad Bank & 0.643 & 0.911 & 0.706 & 0.500 & 0.898 & 0.556 & 0.447 & 0.904 & 0.495 \\
\hline Andhra Bank & 0.725 & 0.906 & 0.800 & 0.862 & 0.955 & 0.903 & 0.588 & 0.923 & 0.637 \\
\hline Bank of Baroda & 0.855 & 0.982 & 0.871 & 0.927 & 1.000 & 0.927 & 0.830 & 1.000 & 0.830 \\
\hline Bank of India & 0.611 & 0.884 & 0.691 & 0.620 & 0.924 & 0.671 & 0.577 & 0.941 & 0.613 \\
\hline Bank of Maharashtra & 0.723 & 0.921 & 0.785 & 0.766 & 0.947 & 0.809 & 0.773 & 1.000 & 0.773 \\
\hline Canara Bank & 0.781 & 0.888 & 0.879 & 0.764 & 0.902 & 0.847 & 0.519 & 0.916 & 0.567 \\
\hline Central Bank of India & 0.943 & 0.961 & 0.982 & 0.997 & 1.000 & 0.997 & 0.960 & 1.000 & 0.960 \\
\hline Corporation Bank & 0.665 & 0.888 & 0.749 & 0.737 & 0.911 & 0.809 & 0.772 & 0.912 & 0.847 \\
\hline Dena Bank & 0.545 & 0.928 & 0.587 & 0.544 & 0.939 & 0.579 & 0.515 & 0.902 & 0.571 \\
\hline IDBI Bank Limited & 0.565 & 0.856 & 0.660 & 0.627 & 0.864 & 0.726 & 0.649 & 0.867 & 0.749 \\
\hline Indian Bank & 0.809 & 0.936 & 0.864 & 0.957 & 0.974 & 0.983 & 0.990 & 0.991 & 0.999 \\
\hline Indian Overseas Bank & 0.913 & 0.962 & 0.949 & 0.932 & 0.966 & 0.965 & 0.921 & 1.000 & 0.921 \\
\hline Oriental Bank of Commerce & 0.933 & 0.964 & 0.968 & 1.000 & 1.000 & 1.000 & 1.000 & 1.000 & 1.000 \\
\hline Punjab and Sind Bank & 0.681 & 0.972 & 0.701 & 0.685 & 0.969 & 0.707 & 0.734 & 0.994 & 0.739 \\
\hline Punjab National Bank & 0.830 & 0.903 & 0.919 & 0.731 & 0.914 & 0.800 & 0.745 & 0.930 & 0.801 \\
\hline Syndicate Bank & 0.638 & 0.919 & 0.694 & 0.898 & 0.965 & 0.931 & 0.854 & 0.958 & 0.892 \\
\hline UCO Bank & 0.780 & 0.956 & 0.816 & 0.797 & 0.915 & 0.871 & 0.774 & 0.913 & 0.847 \\
\hline Union Bank of India & 0.474 & 0.859 & 0.552 & 0.433 & 0.867 & 0.499 & 0.666 & 0.903 & 0.737 \\
\hline United Bank of India & 1.000 & 1.000 & 1.000 & 0.848 & 0.975 & 0.870 & 1.000 & 1.000 & 1.000 \\
\hline Vijaya Bank & 1.000 & 1.000 & 1.000 & 0.911 & 0.982 & 0.928 & 0.974 & 1.000 & 0.974 \\
\hline State Bank of Bikaner \& Jaipur & 0.436 & 0.901 & 0.484 & 0.452 & 0.915 & 0.494 & 0.556 & 0.905 & 0.614 \\
\hline State Bank of Hyderabad & 0.581 & 0.897 & 0.648 & 0.571 & 0.895 & 0.639 & 0.648 & 0.901 & 0.719 \\
\hline State Bank of India & 0.905 & 0.977 & 0.926 & 1.000 & 1.000 & 1.000 & 1.000 & 1.000 & 1.000 \\
\hline State Bank of Mysore & 0.355 & 0.902 & 0.394 & 0.370 & 0.903 & 0.410 & 0.390 & 0.903 & 0.432 \\
\hline State Bank of Patiala & 0.621 & 0.916 & 0.679 & 0.609 & 0.910 & 0.669 & 0.685 & 0.937 & 0.731 \\
\hline State Bank of Travancore & 0.559 & 0.911 & 0.614 & 0.494 & 0.902 & 0.547 & 0.699 & 0.945 & 0.740 \\
\hline
\end{tabular}

Table 7. Ranks - private banks

\begin{tabular}{|l|l|l|l|}
\hline Banks & Rank CRS & Rank VRS & Rank SE \\
\hline Axis Bank & 4 & 8 & 3 \\
\hline Catholic Syrian Bank Ltd. & 1 & 1 & 1 \\
\hline City Union Bank Ltd. & 17 & 14 & 17 \\
\hline DCB Bank Limited & 15 & 18 & 13 \\
\hline Dhanlaxmi Bank & 3 & 4 & 2 \\
\hline Federal Bank & 2 & 2 & 4 \\
\hline HDFC Bank & 6 & 3 & 7 \\
\hline ICICl Bank & 19 & 17 & 20 \\
\hline Indusind Bank & 16 & 20 & 15 \\
\hline Ing Vysya Bank & 11 & 10 & 12 \\
\hline
\end{tabular}




\begin{tabular}{|l|l|l|l|}
\hline Jammu \& Kashmir Bank Ltd. & 7 & 5 & 6 \\
\hline Karnataka Bank Ltd. & 9 & 7 & 9 \\
\hline Karur Vysya Bank & 10 & 12 & 10 \\
\hline Kotak Mahindra Bank Ltd. & 8 & 9 & 8 \\
\hline Lakshmi Vilas Bank & 5 & 6 & 5 \\
\hline Nainital Bank & 14 & 13 & 16 \\
\hline RBL & 13 & 11 & 14 \\
\hline South Indian Bank & 18 & 16 & 18 \\
\hline Tamilnad Mercantile Bank Ltd. & 12 & 15 & 11 \\
\hline Yes Bank Ltd. & 20 & 19 & 19 \\
\hline
\end{tabular}

Table 8. Ranks - public sector banks

\begin{tabular}{|l|l|l|l|l|l|l|l|}
\hline Bank & Rank C & Rank V & Rank S & Bank & Rank C & Rank V & Rank S \\
\hline Allahabad Bank & 23 & 20 & 23 & Punjab and Sind Bank & 15 & 7 & 16 \\
\hline Andhra Bank & 13 & 13 & 14 & Punjab National Bank & 11 & 18 & 10 \\
\hline Bank of Baroda & 8 & 2 & 8 & State Bank of Bikaner \& Jaipur & 25 & 19 & 25 \\
\hline Bank of India & 19 & 17 & 20 & State Bank of Hyderabad & 20 & 24 & 19 \\
\hline Bank of Maharashtra & 12 & 10 & 13 & State Bank of India & 2 & 3 & 3 \\
\hline Canara Bank & 16 & 23 & 15 & State Bank of Mysore & 26 & 22 & 26 \\
\hline Central Bank of India & 3 & 6 & 2 & State Bank of Patiala & 17 & 15 & 18 \\
\hline Corporation Bank & 14 & 21 & 12 & State Bank of Travancore & 21 & 16 & 21 \\
\hline Dena Bank & 22 & 14 & 24 & Syndicate Bank & 9 & 11 & 11 \\
\hline IDBI Bank Limited & 18 & 26 & 17 & UCO Bank & 10 & 12 & 9 \\
\hline Indian Bank & 7 & 9 & 6 & Union Bank of India & 24 & 25 & 22 \\
\hline Indian Overseas Bank & 6 & 8 & 7 & United Bank of India & 5 & 4 & 5 \\
\hline Oriental Bank of Commerce & 1 & 5 & 1 & Vijaya Bank & 4 & 1 & 4 \\
\hline
\end{tabular}

Oriental Bank of Commerce and State Bank of India are the efficiency scores of 1 in 2016 and secured 2017. Indian Bank and Vijaya Bank have secured near perfect efficiency scores during the three years of study. However the private sector banks are better than their counter-parts, public sector banks, even though the correlation coefficient of OBS is .9 and above with all other variables except Share Capital. The Ranks have been computed based on the average efficiency scores are summarized in Table 7 and 8.

\section{Conclusion}

Irrespective of the type of efficiency scores, Catholic Syrian Bank topped among all the private banks in India. Federal Bank and Dhanlaxmi Bank maintained the second and third positions in all types of efficiency scores. SBI, Oriental Bank of Commerce and Vijaya Bank are top performers in maintaining their topper ranks. All the associates of SBI are the poor performers and ranked poorly in the context of all types of efficiency. Few Public sector banks attained the efficiency of 1 and 0.9 . Other public sector banks performed miserably in all spheres of efficiency scores. The private sector banks outsmart in all classified efficiencies than in the public sector banks in the last three years. It is suggested in the study that, consolidation among public sector banks is inevitable to attain efficiencies in the long run.

\section{References}

Berger, A. (1997). Efficiency of Financial Institutions: International Survey and Directions for Future Research. The Wharton Financial Institution Centre, University of Pennsylvania; working Paper No 97-05. 
Bhide, M.P. (2002, Febuary). Banking Sector reforms: A crtical overview. The Economic Politcal weekly, p. 399-408.

De, P. (2004). Technical Efficieny, ownership and reforms: An Economy study of Indian Banking Industry, Indian Economy Review. 39(1):261-94.

Farzipoor Saen, M. (2005). The effect of correlation coefficient among multiple input vectors on the efficiency mean in data envelopment analysis, Applied Mathematics and Computation. 503-21. https://doi.org/10.1016/j. amc.2003.12.117.

Gulati, R.S. (2017). Analysis of banks' intermeidation and operational efficiencies using the two-stage network DEA model: The India case, International Journal of Productivity and Performance Management. 66(6). DOI: 10.1108/IJPPM-03-2016-0055.

Kumar (2012). Evaluating the Performance of Indian Banking Sector using DEA during Post-Reformsand Global financial Crisis. CENTRUM Catolica's; Working Paper Series No 20012-09-0007.

Liang, C. (2008). A DEA model for two stages process: Game approach and efficiency decompostion, Naval Research Logistics. 55(7):643-53. https://doi.org/10.1002/nav.20308.

Luis DanielOtero, G.C.(2012,August).ADEA-tobitanalysis to understand the role of experience and task factors in the efficiency of software engineers, IEEE Transactions on Engineering Management. 559(3):393-400. https:// doi.org/10.1109/TEM.2010.2101078.

Pushkala, M. (2017). Liquidity and OBS items: A comparative study between public and private sector banks in India, SDIDM Journal of Management. 8(1):85-94.

Ray, S (2004). Are some Indian banks are too large? An examination of size efficiency in Indian banking, Journal of Productivity Analysis. 27:41-56.

Ray, S. (2010). Distribution of cost and profit efficiency, evidence from Indian banking. European Journal of Operational Research. 201(1):297-307.

RBI (2017). Statistical Tables related to Banks in India, Reserve Bank of India. Retrieved July 04, 2017, from https://rbi.org.in/scripts/AnnualPublications. aspx ?head=Statistical + Tables...

Singh, N.K. (2004). Efficiency analysis of banks using DEA: A review. International Journal of Advance Research and Innovation. 1(1):120-26.

Venkatesh, P. (2017). Off-Balance Sheet items and Performance Evaluation of Public and Private Sector Banks in India: A DEA approach CFA. Retrieved from /www.arx.cfa/post/IFA-Off-Balance-Sheet-Items-andPerformance-Evaluation-of-Public-and-Private-sectorbanks-in-India-A-DEA-approach-4968.html

Venkatesh, K. et al. (2016, October). Profit efficiency of foreign banks in India in the context of OBS items: A DEA approach, IJESTR. 8(1):1379-86. 